\title{
Overlapping Histories, Co-produced Concepts: Imperialism in Chinese Eyes
}

Total Word Count: 11,131 including notes

Leigh K. Jenco (corresponding author) L.K.Jenco@,1se.ac.uk

Professor of Political Theory, London School of Economics and Political Science, Department of Government

Jon Chappell Jonathan chappell@,hotmail.co.uk

Independent Scholar, London, UK

\begin{abstract}
Many historians of China, particularly those based in North America, insist that the Qing dynasty's territorial expansion was imperial, and comparable to the imperial expansion of other global empires. Other historians, particularly but not only those based in the PRC, continue to resist this interpretation. They argue that dynastic expansion in the Ming and Qing periods was simply a form of nation-state building, akin to similar processes in Europe. Rather than rejecting their claims as a product of Chinese nationalism, we argue that the term "empire" should be (re-)understood as a global co-production, emerging from multiple intersecting histories and scholarly debates about those histories. Doing so challenges influential definitions of empire which rely on a distinction between empires and nation-states, highlighting their dual presence in both Euro-American and Chinese pasts (and presents). This move demands a rejection of periodizations which suggest that empires ceased to exist following the period of decolonization from 1945-1970s. This opens up new avenues of historical and normative enquiry to acknowledge the modern continuity between empires and nation-states.
\end{abstract}




\section{Acknowledgments}

Research and writing for this paper was supported by the Humanities in the European Research Area Collaborative Research Project "East Asian Uses of the European Past: Tracing Braided

Chronotypes," funded by the European Union's Horizon 2020 research and innovation program under grant agreement no. 649307. The authors are grateful for input from their project colleagues Pablo Blistein, Martin Dusinberre, Joachim Kurtz, David Mervart, and Birgit Tremml-Werner. Earlier versions of the paper were presented at the University of London Goldsmiths and the London Comparative Political Theory Research Group Workshop at Kings College London. The authors would like to thank the audiences at all these events and in particular the following individuals for their helpful comments: Rochana Bajpai, Ernest Caldwell, Humeira Iqtidar, and Sanjay Seth. Any errors that remain are, of course, our own. 


\section{Introduction}

Historians have long grappled with the questions of what an empire is, what constitutes imperialism, and whether these terms can be meaningfully divided into temporal categories such as "modern" and "pre-modern" (Morrison 2012a, 1-17; Stoler 2006, 127) . For the imperial historian Frederick Cooper, empires — which he defines as political units which are "large, expansionist" and "reproduce the differentiation and inequality among people [they] incorporate" — have been consigned to history: they disappeared when Britain and France gave up their insistence on the immutable distinctiveness of colonial subjects, rendering their empires unsustainable and ushering in a world of nation states somewhere around 1960 (Cooper 2005, $23,170)$. In contrast to empires, this argument goes, nation states emphasize an imagined commonality among their citizens who are members of a single national community (Burbank and Cooper 2010, 8; Gellner 2008 [1983]). Although imperialism, referring to a wider asymmetrical projection of power beyond stipulated borders, continues to exist within nationstates, Cooper - and others who have followed his influential definition, including Laura Stoler and Paul Kramer-have argued such imperialist phenomena should be distinguished from the noun empire (Kramer 2011, 1350; Cooper 2005, 30). Cooper's definition has since been taken up by scholars of Russian, US and Portuguese imperial formations (Morrison 2012b, 926; Alessio 2013, 77; Frenz 2013, 193).

The stakes of a division between empire and nation-state has been particularly salient in the case of the People's Republic of China. In the early twentieth century, scholars such as Liang Qichao were preoccupied with building a national consciousness to unite the "new people" of China from the ruins of a multiethnic Qing empire (Liang 1994; Schneider 2017). The twenty- 
first century finds some Chinese scholars defending the territorial expansions of the Qing and earlier dynasties into Xinjiang, Tibet, southern China and southeast Asia as forms of "nationbuilding." These more recent scholarly maneuvers respond to arguments by primarily NorthAmerican-based scholars that the Ming and Qing dynasties established imperial forms of rule across both continental and maritime frontiers- "imperial" in the sense that those in power subjugated non-dominant groups by way of political and economic control, which often included the permanent settlement (i.e., colonization) of new populations within a territory (Crossley 2002; Di Cosmo 1998; Pomeranz 2005). ${ }^{1}$ On this definition, late imperial Chinese rule parallels an expansionist project very similar to that imposed by Europeans on societies throughout South and Southeast Asia, the Middle East, and the New World.

The implications of this claim have not been lost on contemporary Han Chinese scholars. Amid the political turmoil that continues to mark Han and non-Han relations in the People's Republic, acknowledging China as an imperial power appears to threaten the territorial integrity of the modern Chinese nation-state (Perdue 1998b, 255; Elliott 2015, 187). Claiming that territories such as Tibet always-already belonged to "China" or that their populations were willingly and naturally attracted to superior Chinese ways of life, some PRC scholars have accordingly attacked American historical scholarship associated with the so-called "New Qing history" for revealing the violence which sustained late imperial state-making on the Chinese frontier ( $\mathrm{Li}, 2015)$. Their content and stridency echoes one of the earliest critiques of Qing revisionist history by the US-based scholar Ho Ping-t'i, who argued that assimilation to Chinese norms, not inner Asian institution-building, uniquely enabled the success of Manchu rule (Ho 1998). Yet even among scholars who acknowledge the violence inherent in Ming and Qing rule over heterogenous, non-Han populations, many—including historians of China based outside the 
PRC, or writing before its founding in 1949-reject comparisons between late-imperial Chinese statecraft and European imperialism. They argue that there is a qualitative difference between aggressive capitalist expansion and pre-modern state building (e.g., Hsu 2015, 163).

Such objections suggest that resistance to viewing past or present Chinese regimes as imperial powers is not entirely a political move, but also a historiographic one that points to different evidence for interpreting the past. Chinese discourse historically has had no single word or reification akin to "imperialism" in European languages. Its existing term for "empire" (diguo) more resembles the ambivalent early modern European usage that labelled the Ming and Qing dynasties 'empires' only in the sense that these were monarchical regimes with authority over vast territories (Fitzmaurice 2014, 17-18). ${ }^{2}$ When the terms for imperialism and colonialism entered the Chinese vocabulary in the early twentieth century (as diguo zhuyi and zhimin zhuyi respectively), they referred more specifically to the (often capital-driven) expansion undertaken by contemporary world powers in Europe and the US, and their Japanese aspirants (Karl 2002, 63-4; Notelhelfer 1971, 82). Using a contemporary social science concept of empire to describe historical Ming or Qing dynastic territorial expansion seems, to many Sinophone historians culturally, temporally and even economically out of joint

Rather than reject out of hand the alternative interpretations of these Chinese critics, or pursue the question of whether "empire" really existed in the Chinese past, in this essay we take a different route. We consider the insights that emerge when "empire" (and its cognates) is recognized as a global co-production: that is, a term whose meaning emerges from multiple intersecting histories and scholarly debates about those histories. ${ }^{3}$ Empire is not, in other words, a term arising within European history against which Qing, Ottoman, or other historical experience is applied and compared. Rather, it is a comparative concept that has been 
transformed by and at the intersection of (inter alia) Qing dynastic expansion, the rise of Chinese national consciousness, European domestic and colonial expansion, and the discourses devised by multiple actors across time to narrate all of these. Recognizing empire as a conceptual coproduction entails, for example, noting how Chinese critiques of the term themselves often turn on constructions of Han Chinese civilization perpetuated by the Manchu Qing, as they explained their activities in Tibet and elsewhere to Han Chinese audiences (Adler 2004, 109; Oidtmann 2018, 16-19). But it also entails taking seriously the substance of those critiques, including how they interpret European and American pasts in relation to putatively Chinese ones. When Han Chinese thinkers confront such pasts - both their histories of territorial annexation, as well as the genealogy of concepts such as "imperialism" or "nation" used to describe the states that resultthey produce understandings of the past that are not reducible to their definitions at point of origin.

Numerous insights flow from this specific examination of empire as a co-production, particularly in relation to the periodization that divides (past) empires from (modern, presentday) nation-states. If scholars of the "New Qing History" use the term empire in part to forestall the anachronistic projection of the Chinese nation-state into the past, their Chinese critics reject the story of China's imperfect transition from "empire" to "nation" first raised by Joseph Levenson more than half a century ago (Levenson 1958). Some of them point rather to a continuity between state unification through territorial expansion and the assimilative activities of nation-building — past and present, in both China and the West—-thereby querying not only what imperialism is, but also when it is supposed to occur. This, we suggest, opens up both normative and historiographic possibilities which are foreclosed by proclamations of the end of empire, or the beginning of a "post-colonial" age. At the very least, understanding "empire" as a 
co-production challenges variants of global history writing which discuss world empires without defining what an empire is (such as Darwin, 2007), and entails a revision of prominent global definitions that clearly separate the unification processes of (nation-)states from the "distinction and hierarchy" internal to empires (Burbank and Cooper 2010; Suny and Kivelson 2017). Similarly, it would challenge analyses of imperialism beyond the confines of global history which (following Hobson and Lenin) define imperialism in relation to the specific capitalist expansion of the modern era (Hobson 1948, 46; Lenin 1970, 20). Insofar as such distinctions between empire and nation, or pre-capitalist and capitalist development, presume a particular kind of periodization - in which empires are presumed to become such only at a particular point in history - this co-produced concept thus brings a different kind of temporality into view: namely, territorial expansionism may be irreducible to historical, large-scale periodizations that enable the identification of "imperial" (or, by extension, post-imperial or post-colonial) epochs. Ultimately, we suggest, the concept of 'empire' does not identify particular time periods so much as enable normative critiques of the abuse of power.

\section{China as Imperial Power: The view of "New Qing History"}

Most of what we might identify as imperial phenomena in late imperial China were not understood by either their administrators or critics in terms of a single project. Rather, such activities were considered under rubrics such as "frontier governance” (bian zheng), "Chinesebarbarian differentiation" (Hua yi zhi bian), or "opening up new land" (kai kuo xin di). These activities constituted a process of what was often called "great unification" (da yitong), a concept which appeared in the Spring and Autumn Annals (c. $5^{\text {th }}$ century BCE) and which was explicitly co-opted by the first emperor of a unified China, Qin Shi Huang (Li 2003, 97). This concept 
evoked the universal charisma of Chinese culture to justify the ever-greater inclusion of non-Han individuals and groups into the orbit of Chinese civilization. Many contemporary historians in China continue to express a preference for using such rubrics over terms such as "imperialism," to avoid the anachronism of applying concepts to historical actors with their own theoretical understanding of their activities (Zhang and Ding 2016, 28).

Before discussing such work in any detail, however, we will briefly outline two distinct models of late imperial Chinese expansion identified by both anglophone and sinophone historians (Xu 2016, 38). The first, particularly prevalent during the Ming and on the southern frontiers of the Qing, tended to focus on ensuring the conformity of subject populations to Hancentric visions of civilization, thereby enlarging the sphere of "all under Heaven" (tianxia). That is, social progress and thus the success of a territorial annexation could be measured (using the unreflective and ethnocentric standards of Chinese civilization) by how moral and virtuous the subject populations became under guidance from the institutions established by the central imperial administration. This meant that indigenous populations in what were considered China's "internal frontiers," such as the Buyi people of Guizhou or the "raw" aborigines of Taiwan, were regarded as backward for not subscribing to Confucian norms (Teng 2006, 26; Weinstein 2014, 125). At least among the educated scholar-officials who administered the empire, consuming and producing such forms of high culture (wen) among both Chinese and barbarians was seen as necessary and sufficient for endowment of a unified political identity flowing from participation in a unified civilizational continuity (Langlois 1980). Imposition of such practices on a subject population, in Chinese and European colonial ideology, were underpinned by "the belief that the process of domination is one of helping the dominated to attain or at least approach the superior cultural, religious and moral qualities characteristic of the center itself" (Harrell 1995, 4). In 
practice, of course, the success of the "conformity" model was typically indexed not through any measures of inherent virtue, but by how often central or local authorities had to intervene to quell rebellions or use force to collect taxes on cleared land (Cheng 2017).

The second model of expansion, prevalent on the northern and western frontiers, was that of the patronage practiced by Qing emperors. This practice probably had its roots in the preconquest Manchu alliance with the Mongols. In 1636, the second Qing Emperor, Hong Taiji, took the title Khan, suggesting patronage of Mongol as well as Manchu cultural symbols (Elliott 2001, 63). After the conquest of Xinjiang and Tibet, the Qianlong emperor (1735-1796) also served as a cultural and religious figurehead in Tibetan and Uighur traditions. While Manchu forces drove territorial expansion in western China, with maps of these regions being labelled in Manchu rather than Chinese (Newby 2005, 252), expansion in Taiwan and southern China rested on Han Chinese settlers who brought with them the notions of cultural superiority outlined above.

Since at least the 1990s, scholars have sought to demonstrate the ways in which Ming and (more commonly) Qing governance shared much in common with other contemporary empires. Peter Perdue was among the first to call for examining the Qing in light of a comparative history of imperialism, citing Qing needs to maintain a large military force for domestic oppression, ensure the loyalty of local elites, and balance bureaucratic uniformity with diverse local cultures as key elements of a shared, global concept of empire (Perdue 1998b, 256). His research dovetailed with renewed attention to Manchu-language scholarly material already underway, which revealed new sources and mechanisms for the foundations of Qing power (Bartlett 1985; Rawski 1996).

These approaches coalesced into a research agenda often associated with the "New Qing 
history," which argues for a global view of the Qing not only or even primarily as a Chinese dynasty but as an inner Asian empire (Waley-Cohen 2004). Historians associated with this approach have demonstrated the Qing's embeddedness in early modern global circulations of people, technologies, and institutions, as well as its indebtedness to inner Asian as much as Chinese ideologies of governance (e.g. Crossley 2012; Elliott 2001). Perdue among others has shown how the Qing paralleled its European counterparts in political and military structures, in part due to its persistent interaction with central Eurasian empires and European technology (Perdue 1998a). By participating in a systematic gathering of information about peoples with whom they were coming into contact through exploration, colonization, and diplomacy, the Qing also engaged in a form of ethnography that Laura Hostetler has associated with contemporary "state-building" processes all over the world, from Tokugawa Japan to the Ottoman empire (Hostetler 2000). These processes strongly match attempts to extract knowledge, translate it into new terms and combine it in ways conducive to control of peripheral populations that was a significant mark of European imperial control of Egypt and the Middle East (Mitchell 2007).

To scholars such as James Hevia, to ignore such obvious similarities between Chinese and European expansion would be to perpetuate "area studies exceptionalism....and notions of China's uniqueness in the age of European global domination (i.e., China as semi-colony)," without fully exploring how and why these historical phenomena have interacted over time (Hevia 1993, 25). The New Qing history also challenges scholars of European empire by demonstrating alternative sites of imperial practice outside European circulations of power. They contribute to a broader scholarship that aims to theorize a wide variety of imperialisms in a comparative frame, while also recognizing the varied expressions of imperial sovereignty even within the confines of one empire. Some of these efforts began as early as the late nineteenth 
century, when contemporary observers of the British empire saw in fact two empires: the empire of white settler colonies and the empire of dominion over non-white peoples (Lieven 2003, 21). Since the collapse of the British Empire in the 1940s and 1950s, an even wider variety of imperialisms have been articulated, beginning with Gallagher and Robinson's suggestion that Britain expanded as much by "informal empire" as through formal colonies (Gallagher and Robinson 1953, 1) and continuing with Said's more recent influential formulation of "cultural imperialism" (Said 1994). Noting the heterogeneity of historical experiences labelled "imperialism," Emma Teng has argued that we should build on this already-existing diversity to extend the term to the Qing case, and in so doing "initiate dialogue and inquiry where before there were none" (Teng 2006, 10).

Such analogic possibilities invite a further, normative argument for seeing Ming and Qing dynastic expansion as "colonial" or "imperial." Applying the vocabulary of imperialism and colonialism to new contexts can be profoundly normatively empowering — that is, it provides a very specific kind of critical purchase on forms of power that would otherwise remain obscured or distorted. For example, naming the Qing presence on Taiwan as "colonial," Teng argues, enables us to resist contemporary PRC claims to so-called "national reunification" on the basis of Taiwan's inherent Chineseness. Without recourse to such vocabulary, she argues, it is more difficult to see how and where prior Chinese regimes employed coercion in order to force assimilation of heterogenous peoples into "China," and impossible then to proceed with Taiwan's “decolonization" from mainland China (Teng 2006, 250-251). Mark Elliott has similarly argued that resisting arguments for Chinese particularity by using such "global categories" would reveal that Chinese territorial expansion was a matter of "conquest and colonization" of non-Han groups, and not a project of "grand unification" as Chinese critics of 
the New Qing History allege (Elliott 2015, 210-11).

Yet, however valuable such scholarly tools may be for doing certain kinds of political work, they must always be used with caution. Historians who allege that Chinese expansionary activity was "imperial" typically assume that that the various means used by the Ming and Qing dynasties to expand dominion over territories and populations amounts to a form of imperialism (Oidtmann 2018, 42; Wang 2011, 3) . Unfortunately, few scholars ever define the term explicitly (e.g., Millward 1998, 17; Herman 2007; Fijeskö 2017, 6-10). James Millward himself notes that while the Qing exhibits the outward characteristics of most empires—namely "territorial vastness, strong centralized power, bureaucratic administration, universalist systems of legitimation, and inclusion of multiple culturally or politically distinct territories in an

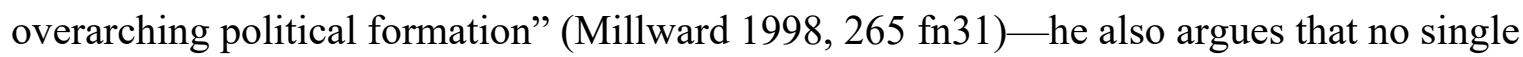
doctrine of imperialism could unify the diverse and distinctive experiences of Qing rule.

\section{Critical Reception and Overlapping Histories}

The historical narratives offered by the New Qing history typically contrast in revealing ways with how many modern Chinese historians have interpreted dynastic expansion. They often argue that Ming and Qing dynastic expansion is qualitatively different from European imperialism, because their relevant phenomena are separated in time. This challenge should be taken seriously because it highlights a fundamental choice for historians: the moment of periodization. Frederic Jameson has called this moment an "absolute historiographic beginning, that cannot be justified by the nature of the historical material or evidence, since it organizes all such material and evidence in the first place" (Jameson 2002, 23). These decisions can and do vastly alter our reading of history. Historians of the Islamic world, for example, have complained 
that assigning a "pre-history" to the rise of Islam in the Arab peninsula suggests an unchanging essence to the religion, tying it to one region and ignoring the significance of its global spread (Bashir 2014, 529). Debate among contemporary Chinese historians has likewise centered on the political and interpretive consequences of labelling certain kinds of historical experience as belonging to one era rather than another (e.g., Liu 2019, 774-5). To many Chinese critics, expansionist activities along Chinese continental and maritime frontiers do not appear either particularly distinct or particularly worthy of condemnation as "imperialist," because the time of their occurrence does not necessarily coincide either with the emergence of modern nation-states in Europe or with the capitalist expansion of the modern era (Ge \& Yin 2016, 10).

Understanding such divisions of time in relation to imperialism requires first understanding the history of the terms diguo zhuyi (imperialism) and zhimin zhuyi (colonialism), as well as the history of Chinese conceptions of dynastic expansion and nation-building. This history reveals the extent to which the application of the term "empire" remains entangled with the pasts of both European and Japanese nation-states, including the empires upon which they were built. Diguo zhuyi first emerged in Chinese discourse at the turn of the twentieth century in writing which was specifically concerned with imperialism as a novel malady on the global stage (Karl 2002, 63-64). The terms gained greater currency when Communist theorists emphasized the close connection between the expansion of European capitalist development and the subordinate global position into which China was thereby thrust (Wang 2012, 164). Writing in 1926, Chen Duxiu, co-founder of the Chinese Communist Party, explicitly distinguished between the activities of expansionist Chinese states and "modern" European imperialism. He argued that "invasion into other countries is surely a characteristic of imperialism, but the invasion by the ancient Roman Empire and the Chinese West[ern] Han dynasty for their territorial expansion can 
only be labelled as feudal imperialism, which is totally different from today's modern imperialism" (cited in Wang 2012, 172).

Equally significant and related, however, is the fact that during this same period in the late nineteenth and early twentieth centuries, European contemporaries such as J. A. Hobson and Lord Acton were commenting on the emerging conflation of national and imperial ambitions. The sociologist Krishnan Kumar identifies this period as the height of convergence between "nation" and "empire" as both ideals and practices. Critics such as Hobson noted how nationalism, underpinned and driven by capitalist expansion, threatened as much as imperialism to "overflow its natural banks and absorb the near or distant territory of reluctant and unassimilable peoples" (Hobson 1902, 6; cited in Kumar 2010, 132). It was also at this time that the processes of "conquest, colonization, and cultural change" taking place across Europe since the early middle ages — processes identified as key to "the making of Europe" and its nationstates (Bartlett 1993) — were being written into national narratives of France, England and Prussia as processes of nation-building (Weber 1976; Bell 2007). In other words, at the very time these nations were deepening involvement in overseas colonies, they were also engaged in the parallel activity of swallowing up their own internal minorities - a process historians and social critics would later identify with "internal" colonialism (Hechter 1975; Byrd 2011). For our purposes, the most prominent example of this relationship between expansionary processes and national self-identity was the drive among competing European nations to secure trading rights in China, culminating in a scramble for concessions in the late 1890s (Bickers 2011).

The point here is not to dismiss use of a term like "empire" out of hand solely on the basis of its own imperialist genealogy. Rather, we hope to point out that the intersecting histories of a term's application contribute to its general valence, including its conceptual relationship to 
other terms such as "nation." This is true for European as much as Chinese usage of the term. In the late nineteenth and early twentieth centuries, when European thinkers were noting the explicit pursuit of empire by nation-states in a global competition for domination and resources, they also noted the pursuit of nationalism using imperial means. The nation "came to be associated with the power-status of the established national culture, and the imposition of its values on ethnic or cultural minorities both within and beyond the body politic was now considered essential" to national development (Mommsen 1990, 215; discussed in Kumar 2010, 132). The paradigmatic referents for terms such as "nation" and "empire" in European history and contemporary politics were therefore mutually implicated rather than distinctly delineated when they entered Chinese discourse. As Ge Zhaoguang has observed in his own ruminations on the nature of empire, "the modern nation-state is a product of the traditionally centralized empire, preserving remnants of the ideology of empire, from which we can see the histories of both were intertwined" (Ge 2017, 23).

At the very same time, many late Qing and Republican-era scholars were using a different set of inherited terms to discuss activities, discourses and attitudes identified as "imperial" by such scholars as Teng, Elliott and Millward - even as they were in the process of producing a new language for national self-identity in conversation with both European and Japanese experience. These terms drew from long standing traditions within Chinese thought initially deployed in competing narratives of the modern Chinese nation in the period before the collapse of the Qing in 1911. Initially, anti-Manchu Han nationalist revolutionaries demanded a purge of non-Chinese elements within the new state, but eventually there emerged convergence on preserving the Qing as a territorial, albeit not political, model for unifying the nation's borders (Schneider 2017, 51). Retaining the borders of the Qing's multi-ethnic empire protected access 
to natural resources and provided bulwarks against foreign assault along China's northern and western sides, but it also entailed writing a new kind of history that could justify including these predominantly non-Han territories as always-already a part of "China” (Duara 1995, 33-41). Following Liang Qichao's influential example in his 1902 tract "Preface to Chinese history," in which he explicitly reduced two thousand years of "Asian" history into a version of "Chinese history," Chinese historiography began focusing on how the charismatic influence of Chinese civilization attracted ever more non-Han peoples within its orbit (Liang 1994, 2). These visions drew on longstanding beliefs in the inherent "assimilative power" (tonghua li) of an autochthonous Chinese culture to spontaneously induce the "sinicization" (Hanhua) of nonChinese groups and individuals (Schneider 2017, 4). Such assumptions played a major role in Sun Yat-sen's influential formulation of the principle of minzu (nationality), in which he predicted the eventual absorption of "weak and small peoples" into the dominant Han majority (Leibold 2004).

Claims like Sun's have persisted throughout the Maoist period and well into the post-1978 reform era (Farquhar 1968, 188; Schneider 2001, 136). They exhibit obvious features of "imperial" rule, insofar as they justify cultural violence to non-Han populations in the name of a superior civilization destined to absorb them. But there have also been counter-discourses within Chinese scholarship that explored alternatives to Sun's and Liang's vision of a racially and culturally homogenous community (Leibold 2006). These efforts, most prominently mobilized in the 1930s to counter imperial Japanese territorial claims over vast reaches of East Asia, sought to resolve the problem of Han domination of a multi-ethnic state by challenging the idea of a unified or homogenous Zhonghua minzu (the "Chinese nation") (Jenco 2019). Their project of "historical geography" (lishi dilixue) was both subversively anti-traditional and self-consciously 
modern; they drew particular attention to the violence that attended the historical assimilation of minority peoples, and to the contingency of the labels used to distinguish "Chinese" from “barbarian” or other ethnic groups (e.g., Tong 1934, Gu 2010). Yet its main adherents tended to sustain their critique without recourse to the concept of "imperialism," and explicitly identified their work in terms of a continuity with the "frontier studies" (bianjiang xue) undertaken by statecraft (jingshi) scholars of the mid- to late-Qing, such as Wei Yuan and Gong Zizhen (Sun and Wang 2013, 3).

Such interest in alternative concepts to empire in the 1930s shows that it was not only as a consequence of European, capital-driven colonial incursion that "imperialism" took on its particular valence for Chinese audiences, but also due to the activities of scholars and policymakers working for the Japanese empire. In fact, the first mention in Chinese of the Qing as an "empire" was in the 1895 Treaty of Shimonoseki, which admitted Qing defeat and ceded Taiwan and the southern Liaodong peninsula to Japan. Mark Elliott suggests that this attribution was likely an attempt by negotiator Li Hongzhang to make China appear more equal to Japan, a move which subsequently facilitated later identification of the Qing as an "empire" among Chinese intellectuals such as Zhang Bingling (Ou 2014, 37-38). In the same article, Elliott ascribes later Chinese reluctance to apply the term "empire" to the Qing as related to China's coincident self-identity as a nation-state (Ou 2014, 31). But the discussion here brings other possibilities into view, particularly given the overlapping histories of "nation" and "empire" as these concepts took on new life in Chinese terms. The reluctance to use the term empire may be equally related to the fact that the Qing found its identity as such in a humiliating situation of defeat, not only in a context of European colonial domination but also more proximately at the hands of an imperial power that decades later would formally annex Chinese territory. These 
contexts continue to exert direct influence on this debate. Japanese imperial interests directly motivated research on Manchukuo, including — as Chinese critics have pointed out — the collection of Manchu-language materials by Japanese scholars, which subsequently formed the key sources for the New Qing history (Li 2016, 16; Xu 2016, 8). ${ }^{4}$ In what follows we examine current Chinese responses to the New Qing history by taking account of how these overlapping contexts have resulted in a multivalence for the term "empire."

\section{Imperialism and its Others: Responses to the New Qing History}

Recent resistance to using "imperialism" to describe the Chinese past continues to center on the issue of Han domination of a multi-ethnic state. It is therefore unsurprising that some of this scholarship is inherently political and ahistorical—such as Ma Dazheng's assertion that “China has been a multi-ethnic unified country for more than 2000 years," or Zhao Tingyang's insistence that the Zhou dynastic concept of governing for "all under Heaven" was capable of uniting diverse cultures to create "long-term peace which lasted for centuries in China" (Ma and Shan 2012, 67; Zhao 2009, 9). However, more historically-minded scholarship has acknowledged the violence inherent in Chinese expansion, and the contingency of the modern borders of the PRC which depended on this process. Yet these scholars insist that these processes are qualitatively, and in some cases temporally, distinct from European imperialism. Here we will consider two variants on this challenge, articulated by some of the most influential thinkers in this field and often in dialogue with one another. The first variant questions the difference between the violence inherent in state building and that deployed in imperial expansion, while the second draws a distinction between Chinese colonial expansion and "modern" western imperialism. 
The first is the distinction is proposed by Wang Rongzu, a historian at Taiwan's National Central University. Operating outside the People's Republic, Wang is not subject to the growing political sensitivity there surrounding the conceptualization of the history of China's western regions. Nevertheless, he notes that one of his motivations for rejecting new Qing historians' labelling of China as an empire is that this is not a new theory, but a continuation of the Japanese imperialist theories of the 1930s which served to justify their presence in China as liberators of Manchus, helping them to establish a separate Japanese puppet state (Wang 2016, 337). Against this background, Wang raises an important challenge. Firstly, he points out that many modern states are multi-ethnic. That the Qing ruled over diverse ethnicities did not make them an empire, as Cooper's definition would suggest, but rather makes them similar to modern multi-ethnic states, such as the US, Russia and even Japan, where ethnicity and nationality are generally distinguished from each other. He suggests that within this history there was a process of "sinicisation" (hanhua) in which groups were culturally assimilated into the mainstream, but he does not attribute any unique power to this process. Instead, he likens it to the modern assimilative process of westernisation (xihua) (Wang 2016, 328-9).

Not only is China not unique in being a multi-ethnic state, but Wang also points out that it is far from unique in being a product of violent state-making. Nevertheless, he rejects the assertion that this violence was imperial. For example, he suggests that the Kangxi emperor's military campaign against the Zunghar leader Galdan was a territorial expansion driven by the need to secure the state's borders, something clearly distinct from imperial expansion:

This kind of policy arrangement and...so called "modern imperialism," which aims to extract resources, take advantage of cheap labor and expand market opportunities, is 
certainly not the same, therefore we have to clarify the concept of colonization (zhimin).... Expansion which arises out of a purely defensive motive, whether or not it ought to be declared positive, has far more legitimacy than expansion which arises from an economic motive (Wang 2016, 333).

For Wang, the distinction between European extractive imperialism and Qing state building does not render China exceptional because "no matter whether ancient or modern, in China or outside, to unify almost necessarily requires annexing territory to be realized" (Wang 2016, 334). Wang explicitly rejects taking the contemporary borders of the People's Republic as a given historical telos, and acknowledges that Xinjiang and Tibet's incorporation into China were both violent processes and products of historical contingency (Wang 2016, 333). Yet, the difference in motive, he argues, renders "colonialism" an inappropriate label.

The second challenge admits that Chinese expansion could be violent and colonial—with some critics even rejecting Wang's idea the idea the Kangxi emperor's motives were purely defensive (Yao 2016b, 310) — but insists on qualitative differences between European and Chinese imperial practices. Ge Zhaoguang, of Shanghai's Fudan University, offers an influential and representative view. For example, regarding the gaitu guiliu policies in southwest China (which replaced indigenous headmen with Qing officials), he argues that 'we absolutely cannot doubt that this kind of civilizing (wenming hua) process was the same as a colonizing (zhimin hua) process and was not only the spreading of prosperity but was filled with blood and fire' (Ge 2016, 7). For Ge, the violence inherent in Chinese expansion and integration of different peoples renders it colonial (or imperial - two terms he seems to use interchangeably).

His position is striking, given that he, like other scholars in the PRC, is operating within a 
political context in which discussion of policy in China's historical borderlands is increasingly restricted. Ge himself also remains involved in state activities including serving as a member of the National Textbook Committee. At the same time, however, Ge insists that these civilizing processes were distinct from nineteenth-century European expansion:

When comparing the Ming and Qing gaitu guiliu process with the colonial advance of England, France, Spain, Portugal and Holland, it is important to look at three differences. Firstly, there is the distinction between going overseas to conquer and gradually expanding from the centre to the borderlands. Secondly, the purpose of one is to plunder resources, while that of the other is integrating $[$ naru $]$ territory into the empire. Thirdly, one maintains the differences between metropole and colony, while the other, through a gradual process of sinicization, assimilates foreign groups (Ge 2016, 8).

Unlike Wang, Ge accepts the label colonial for Chinese practices, but implies this is inherent to state-making and is qualitatively different from nineteenth-century European imperialism. Ge adopts Byung Ho Lee's assertion that China was a "patrimonial imperial state": unlike a nationstate it was not formed through one ethnicity asserting self-determination, and unlike an empire it did not rule through insisting on the maintenance of ethnic difference (Ge 2016, 8; Lee 2011, 7). Instead, different ethnic groups were assimilated to form one new national identity.

One distinctive way in which that assimilation took place in China, Ge argues, is through those very gaitu guiliu policies, which enforced Han social customs and practices on minority peoples of the southwest. Ge argues that such policies aimed to make these peoples "imaginable" [xiangxiang] but one could equally say "legible," to the Chinese state (Ge 2016, 5). Despite these 
claims to Chinese exceptionalism, Ge's argument and language converge with accounts that emphasize the violence of state building in both empires and nations. The social scientist James Scott has argued that states aim to make the societies they govern more legible through simplifications and homogenization to control them. These strategies are as visible in the building of colonial states, such as in the Spanish Philippines, as they are in nineteenth century France (Scott 1998, 70-78). For Scott, it is a myth that any nation is formed of one unconstructed ethnicity; rather, he argues, nation-states are reliant on a process of homogenization similar to that which Ge describes in southwest China.

This insistence on a qualitative distinction between Chinese and European imperialism is also taken up by Yao Dali, a colleague of Ge's at Fudan. Yao suggests that at the root of the disputed meaning between European and Chinese thinkers is how we periodize imperialism. Chinese thinkers, he argues, regard imperialism as a type of invasive policy in which strong capitalist countries "oppress, enslave and exploit backwards countries," whereas Western thinkers link the word "colonia" to its Roman roots and therefore see imperialism as a transhistorical process of "discovery, opening up and developing" (Yao 2016b, 305). Yao concludes that

Colonial behavior is the norm among all peoples and within all stages of societal development ... [but] capitalist resource extraction developed at almost the same time as modern colonialism [xiandai zhiminzhuyi] and was especially repulsive and unacceptable, increasingly giving rise to a new intellectual tide [of nationalism] (Yao 2016b, 308).

As a result, Yao argues that while the label colonial is applicable to Chinese state 
building activities, it is qualitatively different from modern imperialism. For Yao, "modern imperialism", that is, the reification "imperialism" rather than the activities of early modern empires, emerged around 1825. From this point on, "the principle driver of [western expansion] was the contest over profit, markets, raw materials and the export of capital" (Yao 2016a, 355). Modern imperialism is distinctive, and modern, because of its imbrication with the emergence of capitalism.

As a mainland Chinese scholar, potentially subject to the political pressures created by the PRC's increasingly coercive policies in Xinjiang, Yao does not deny that colonialism exists in China. In fact he emphasizes that if 19th and 20th century colonialism was more 'colonial' it was not because it was more violent or coercive, but rather because it maintained a sharp divide between the metropole and colonies (Ho 1998, ;Yao 2016b, 307). It was this divide which gave rise to nationalist sentiment.

Yao's point is that imperialism cannot be viewed as a transhistorical phenomenon; different kinds of colonialism exist in different historical phases, and imperialism is distinctively modern. He echoes Peter Perdue, who has pointed out that productive comparisons across empires do not try to erect models which are divorced from historical time (Perdue 1998b, 259). Thus, it is not just what imperialism is that renders Qing activities distinct from those of European empires, but also when it is. In his two recently published general histories of China, for example, the US-based historian Hsu Cho-yun has argued that China only joined Europe on the path towards the development of a nation state when it was faced with the threat of foreign imperialism. Prior to this, the Chinese cultural sphere was linked not by empire but by the cultural unity he labels tianxia, "all under Heaven," closely intertwined with the state (Hsu 2015, 13; Hsu 2012, 179). For some historians, the difference seems to lie more in how the past is 
periodized than in what specifically it contains: empires, and the violent processes of imperialism that presumably accompany them, are differentiated from the (arguably equally violent) processes of nation-state building which succeed them solely by how they are organized in time. In contesting application of the term "imperialism" to specific points of the Chinese past, Chinese critics effectively draw attention precisely to this conceptual weakness in attempts to compare empires.

It seems, then, that if we want to make comparative claims about imperialism we need to explain both if and how imperialism is distinct from state-building, and why imperialism in its modern, capitalist form is not fundamentally distinct from its early modern variant. By answering these challenges, we may arrive at new insights as to what imperialism is and, potentially, also what it might mean to advance "post-colonial" or "post-imperial" criticism.

\section{Empire as a conceptual co-production}

We contend that assertions by Chinese critics that European imperialism and Qing state building are fundamentally distinct should not be dismissed simply as an instance of Chinese exceptionalism. Rather, they reflect a long history of Chinese engagement with the concept of "empire," which extends beyond the borders and history of the contemporary PRC and in some ways does not always serve its interests. If terms such as "imperialism" are going to work on a global scale that does not reduce all historical phenomena to European categories, we must acknowledge that the meaning of empire can be extrapolated only through examination of the similarities and differences in interpretations of it across cultural contexts. The lack of agreement among historians of China about when imperialism was and was not present encourages us to expand the global temporal scope of the term, and to reconsider the time of empires as well as of 
imperialism. In doing so, we are confronted with the insight that "imperialism" is not a descriptive so much as a normative concept: it names and condemns a particular expression of power, rather than specifies historical processes that endure over time.

Wang Rongzu's equation of US multiculturalism with the Chinese management of ethnic diversity, for example, highlights the difficulty of periodizing empires as state formations, because it suggests a continuity that challenges Cooper's chronology and typology. How far, we might ask, did the "world of nation-states" really spell the end of empires? Cooper has argued, influentially, that "in one way or another, [empires] had to articulate difference with incorporation. Difference had to be grounded in institutions and discourses" (Cooper 2005, 23). Yet this argument leaves space to question how distinct from contemporary nation states "empires" really are. On this view perhaps the US and China are still empires rather than nations. After all, China maintains an "ethnic minority status" policy which, nominally at least, claims to respect the diversity of different constituencies who occupy discrete territory in order to justify their inclusion in the polity. Similarly, the US federal government grants specific legal privileges, including limited scope for self-determination, to Native American populations living on reservation lands, while continuing to curtail recognition of their full autonomy as a means of ensuring national unity (Duthu 2009; Richardson, 2009).

The assertion that imperial behavior transcends historical epochs and is present in all state building processes is not a new observation; in fact, it resonates with recent scholarship that notes the difficulty of applying the binary of nation and empire to real state formations. Historians describe the Soviet Union, for instance, as a state with "both imperial and national characteristics," exercising sovereign rule organized by hierarchized differences more in the form of an empire than a typical nation-state (Kivelson and Suny 2017, 4-5). Justin Jacobs has 
also deemed the Chinese state a "national empire," in which "territorial and human heterogeneity" — which he takes to be the hallmarks of empire-have now become "nationalized to conform to new narratives of post-revolutionary political legitimacy" (Jacobs 2016, 234).

Oddly, however, even historians who emphasize how much contemporary nations resemble empires cleave to the view that "empire is fundamentally different from what eventually emerged as the ideal type of the nation-state" (Kivelson and Suny 2017, 3; Kumar 2010, 121, 137). One result of this commitment is that scholars routinely project into Chinese (and other) pasts a vision of empire as a state comprised of differentiated, multi-ethnic populations, without noting that this definition would not have been legible even to contemporary Europeans-who until the nineteenth century tended to associate empire more with the projection of sovereignty over space, than with rule over differentiated, subjugated populations (Pagden 1995, 12-13, 14). This anachronism has consequences for Chinese as well as European history. In the Chinese case, it informs historical narratives about the transformation of China from a universal normative civilization to merely one nation-state among others- which Joseph Levenson and John Fairbank famously identified as a movement from the unity of tianxia (“all-under-Heaven”) to the particularity of guo (a particular "state" or "nation") (Levenson 1952; 1958; Fairbank 1978). By posing a dichotomy between an empire's unification of difference and the homogenizing, levelling processes of the nation-state, moreover, such narratives enforce amnesia about the ongoing "internal" imperial projects pursued by contemporary European and American powers in the name of promoting the dominance of their own nation (Byrd 2011, 38-43).

One response to the challenge that imperialism is present in all state building might be to suggest, as Justin Mueller has claimed, sovereign rule itself is always-already imperial (Mueller 2016, 434). State-making requires the neutralization of domestic rivals and the indoctrination of 
its citizenry in processes which may themselves be seen as a form of imperialism. Vladimir Lenin, among others, gave voice to such insights when he argued that the unevenness of development in countries such as Russia and the US was parallel to the kinds of global inequality that consumed the surplus products of capitalism (Ëtkind 2011, 20-21). Terms such as "internal imperialism" have thus been deployed as a means of drawing attention to the violence and oppression which marked the experience of marginalized populations even within a shared state (Gutiérrez 2004). What is perhaps most remarkable about the critical dissensus surrounding discussions of imperialism is precisely that dissenters tend to view this continuity between what we might identify as internal "socialization" processes and external "integration" processes as a reason to reject the term "imperialism," rather than adopt it. But this leads us to ask: What are the consequences of this choice, and what kinds of insights does it make possible?

In so far as there may be continuity between internal and external processes of oppressive rule, imperialist processes appear to have a temporality out of step with typical historicizations that see imperial expansion as an epoch: that is, as a "stage" on the way to nationhood or decolonial emancipation for many post-colonial states; as part of a history that modern liberal democracies must mark and overcome through reparations for past social inequalities, such as in regard to aboriginal claims in Australia and North America; or even (as in the early modern period) a natural next step for the grandizza associated with the attractiveness and might of domestic republican liberty (Armitage 2006; Ivison 2002; Duara 2004). Part of the trouble critics have in applying "imperialism" to parts of the past now claimed by the PRC may arise, then, not from a misunderstanding, but an insight, about the temporality of such imperialist processes. In their persistence, continuity, and reproduction, such processes do not happen once and for all in history, or even recur under particular conditions to mark epochs of expansion. 
Rather, they persistently repeat themselves over and over within the micro-spans of individual lifetimes and family generations.

If "imperial" processes recur ceaselessly on a micro-level in conventions that shape individual socialization, and on a macro-level in institutions that culminate in state-makingboth within and outside designated domestic or state contexts - then it seems any hope for postcolonial emancipation would necessarily have to lie in a cultural critique: to move beyond imperialism would be to advance criticism of the very socialization processes that replicate themselves at different scales and on different levels over time, rather than of any particular political or economic project associated with territorial expansion in a given epoch. The temporality of empire's overcoming is thus not (only) historical, then, but personal and generational. One such possibility is sketched by Iris Young, who identifies cultural imperialism - the marking out of certain social groups as both invisible and "other" to a more privileged dominant group — as one of the "five faces of oppression" in modern society (Young 1990, 58-59). The solution to cultural imperialism, Young argues, lies in cultivating positive subjectivity among members of marginalized social groups, and resisting the imposition of a dominant culture's way of life on one's own.

If this is true, then New Qing historians - and all scholars interested in how and why Chinese identity becomes transposed onto specific territorial space — might need to more carefully pry apart normative from empirical arguments, as a means of specifying the distinct premises underlying each. PRC claims to contested territories such as Taiwan and Tibet are problematic not because they are based on a factually erroneous continuity between what was a multi-ethnic empire and what now should be an ethnically homogenous nation-state; after all, similar arguments could be, and have recently been, put to the existing governments of Spain, 
Great Britain, and other European powers (e.g., Declaració Dels Representants de Catalunya 2017). Rather, such claims are reprehensible because they are sustained by violence that lacks a moral defense. What is really at stake is not whether or not a particular state formation is imperial, or what the definition of empire might be, but rather how violence of all kinds is used to promote or naturalize inequality in the service of rule.

\section{Conclusion}

Rather than ask if imperialism is or is not present in Chinese history, we have tried to demonstrate the ways in which viewing empire, nation and related terms as co-productionsterms whose meaning emerges irreducibly from the intersection of multiple overlapping histories and discourses - can throw light on how connections between state-making, assimilation, and territorial expansion are historically narrated. European nation-state-making, implicated in violent processes of homogenization and systematization, has been distinguished from imperialism for the same reasons that some critical Chinese historians separate European capitalist imperialism from pre-modern Chinese expansion: both processes are seen as out of imperial time.

The co-production of empire has revealed that its application may turn less on the evidence of "objective" historical comparison and more on the kind of critical work the label "imperialism" can do. In other words, the greatest value of the term "imperialism" may lie in its normative thrust — that is, it invites a particular form of value-judgment about the nature of violence, including when in time that violence and its distinctive forms of oppression are supposed to happen or be overcome. On this view, labels such as "empire" and "imperialism" name and condemn a particular expression of power, rather than delineate real historical entities 
that endure in unambiguous ways over time and space. This insight could be applied as easily to Yao's assertion that modern imperialism was qualitatively worse than previous expansions, as to Teng's claims that Chinese activities on Taiwan were colonial. Both use the term to make a normative argument about where (and when) power has been inappropriately extended.

At the same time, once we highlight the continuity between empires and nations, it becomes meaningful to ask how and why all states within the global system now choose to call themselves nations, regardless of whether or not they had inherited the territory — and some of the practices - of a pre-existing empire. Abandoning the clear-cut distinction between empires and nation states allows us to highlight continuities between the age of empires and the postcolonial world, opening up new areas of historical enquiry as we reconsider both the novelty and the uniqueness of the nation as a state formation. Such enquiries throw further light on how, in Tim Brook's words, "conquest is historically embedded in nation formation in Asia," by expanding our scope to incorporate indigenous terms of art that operated in conceptual frameworks that sometimes link to empire, and sometimes do not (Brook 2016, 966, 968). Viewing these frameworks as co-produced, moreover, decenters historically dominant cultures (whether or Chinese or Western) as exclusive sites of conceptual innovation. Brook, for example, shows how the imagined unity behind both Ming and Qing expansion was based on the hybrid Mongol concept of a "great state," drawn from multiple Chinese and Mongol precedents (Brook 2016, 961).

It may be argued that such a wide application of imperialism makes it amorphous, but arguably the term has always taken on diverse forms which do not make it reducible to specific phenomena. It also allows us to question the assertion that a world solely comprised of nation states has come into being. Rather than assume we already know what imperialism is, we should 
perhaps focus more explicitly on identifying and critiquing specific forms of violencerendering us better able to address those forms of violence, wherever and whenever they occur. 
ADLER, JOSEPH A. 2004. "The Qianlong Emperor and the Confucian 'Temple of Culture' (Wen Miao) at Chengde.” In New Qing Imperial History: The Making of Inner Asian Empire at Qing Chengde, edited by James A. Millward, Ruth W. Dunnell, Philippe Foret, and Mark C. Elliott, 109-22. London: Routledge.

ALESSIO, DOMINIC, 2013. ““...Territorial Acquisitions are Among the Landmarks of our History': The Buying and Leasing of Imperial Territory," Global Discourse 3(1):74-96. ANDERSON, BENEDICT R. 1983. Imagined Communities: Reflections on the Origin and Spread of Nationalism. London: Verso.

ARMITAGE, DAVID, 2006. "Empire and Liberty: A Republican Dilemma" in Republicanism: A Shared European Heritage edited by Martin van Gelderen and Quentin Skinner, vol.2, 29-46. Cambridge: Cambridge University Press.

BARTLETT, BEATRICE S., 1985. "Books of Revelations: The Importance of the Manchu Language Archival Record Books for Research on Ch'ing History." Late Imperial China $6(2): 25-36$.

BARTLETT, ROBERT, 1993. The Making of Europe: Conquest, Colonization and Cultural Change 950-1350. London: Allen Lane.

BASHIR, SHAHZAD, 2014. "On Islamic Time: Rethinking Chronology in the History of Islamic Societies." History and Theory 53(4):519-544.

BELL, DUNCAN, 2007. The Idea of Greater Britain: Empire and the Future of World Order, 1860-1900. Princeton (N.J.): Princeton university press.

BICKERS, ROBERT, 2011. The Scramble for China: Foreign Devils in the Qing Empire, 18321914. London: Allen Lane.

BURBANK, JANE and COOPER, FREDERICK, 2010. Empires in World History: Power and 
the Politics of Difference. Princeton N.J.: Princeton University Press.

BYRD, JODI A., 2011. “'Been to the Nation, Lord, but I Couldn't Stay There': American Indian Sovereignty, Cherokee Freedmen and the Incommensurability of the Internal.” Interventions 13(1):31-52.

CHENG YIN-YI, 2017. "Yangzhan shenghua, yuanfu bianmeng? Kang Yong chao 'sheng fan' guihua yu fanren fenlei tizhi de xinggou (Being Enlightened by Empire? Naturalization of Shengfan and Establishment of Fan Classification System under Emperors Kangxi and Yongzheng)," Taiwan shi yanjiu (Taiwan History Research) 24(2):1-32.

COOPER, FREDERICK, 2005. Colonialism in Question: Theory, Knowledge, History. Berkeley: University of California Press.

CROSSLEY, PAMELA KYLE, 1990. "Thinking About Ethnicity in Early Modern China.” Late Imperial China 11(1):1-35.

CROSSLEY, PAMELA KYLE, 2002. A Translucent Mirror. Berkeley: University of California Press.

CROSSLEY, PAMELA KYLE, 2012. "The Dayi Juemi Lu and the Lost Yongzheng Philosophy of Identity." Crossroads - Studies on the History of Exchange Relations in the East Asian World 5(0):63-80.

DARWIN, JOHN, 2007. After Tamerlane: The Rise and Fall of Global Empires, 1400-2000. London: Allen Lane.

Declaració Dels Representants de Catalunya (Catalan Declaration of Independence). 2017. http://www.ara.cat/2017/10/10/Declaracio_Independencia_amb_logo_-1.pdf.

DI COSMO, NICOLA, 1998. “Qing Colonial Administration in Inner Asia.” The International History Review 20(2):287-309. 
DUARA, PRASENJIT, 1995. Rescuing History from the Nation: Questioning Narratives of Modern China. Chicago: University of Chicago Press.

DUARA, PRASENJIT ed. 2004. Decolonization: Perspectives from Now and Then, Rewriting Histories. New York, NY: Routledge.

DUTHU, N. BRUCE, 2009. American Indians and the Law. London: Penguin.

ELLIOTT, MARK C. 2001. The Manchu Way: The Eight Banners and Ethnic Identity in Late Imperial China. Stanford: Stanford University Press.

ELLIOTT, MARK C. 2015. "The Case of the Missing Indigene: Debate over a 'SecondGeneration' Ethnic Policy” The China Journal 73:186-213.

ĖTKIND, ALEKSANDR, 2011. Internal Colonization: Russia's Imperial Experience. Cambridge: Polity.

FAIRBANK, JOHN K., 1978. "Introduction: The Old Order." In The Cambridge History of China. Volume 10, Part 1 Volume 10, Part 1, edited by John King Fairbank. London: Cambridge University Press.

FARQUHAR, DAVID M. 1968. "Chinese Communist Assessment of a Foreign Conquest Dynasty" in History in Communist China edited by Albert Feuerwerker, 175-188. Cambridge, Mass.: M.I.T. Press.

FISKESJÖ, MAGNUS, 2017.“The Legacy of the Chinese Empires Beyond 'The West and the Rest'." Education about Asia 22(1):6-10.

FITZMAURICE, Andrew, 2014. Sovereignty, Property and Empire, 1500-2000. Cambridge: Cambridge University Press.

FRENZ, MARGRET, 2013. "Representing the Portuguese Empire: Goan Consuls in British East Africa C.1910-1963" in Imperial Migrations: Colonial Communities and Diaspora in the 
Portuguese World, edited by Eric Morier-Genoud and Michel Cahens, 193-212. London:

Palgrave Macmillan.

GALLAGHER, JOHN and ROBINSON, RONALD, 1953. "The Imperialism of Free Trade."

The Economic History Review 6(1):1-15.

GELLNER, Ernest, 2008 [1983]. Nations and Nationalism. Oxford: Blackwell.

GE ZHAOGUANG, 2016. "ge shi zhi jian: youguan 'hanhua', 'zhimin', yu 'diguo' de zhenglun

- Between Name and Reality: Disputations on Sinicization, Colonization and Empire)." Fudan

xuebao (shehui kexue ban) - Fudan Journal (Social Sciences), 6:1-11.

GE ZHAOGUANG and YIN SHENG, 2016. "Cong lishi kan Zhongguo, Yazhou, rentong yiji jiangyu: guanyu 'zhai zi Zhongguo' de yi ci tanhua (A Historical Perspective on China, Asia, Identity and Territory: A First Discussion of 'Here in China I Dwell')" in shufang wei yuan: gudai zhongguo de jiangyu, minzu yi rentong (Distant Regions are not Far: Ancient China's Territory, Peoples and Identity) edited by Wang Rongzu, Ge Zhaoguang, Yao Dali and Xu Wenkan, 1-12. Beijing: Zhonghua shuju.

GE ZHAOGUANG, 2017. Here in 'China' I Dwell: Reconstructing Historical Discourses of China for Our Time. Leiden: Brill.

GU JIEGANG, 2010. "Xu lun 'minzu' de yiyi he Zhongguo bianjiang wenti” (An Overview of the Meaning of 'minzu' and China's Frontier Problems) in Gu Jiegang Quanji (The Collected Works of Gu Jiegang), 1st ed., vol. 36, 123-132. Beijing: Zhonghua shuju.

GUTIÉRREZ, RAMÓN A., 2004. "Internal Colonialism: An American Theory of Race.” Du Bois Review, 1(2):281-295.

HARRELL, STEVAN, 1995. Cultural Encounters on China's Ethnic Frontiers, Studies on Ethnic Groups in China. Seattle: University of Washington Press. 
HECHTER, MICHAEL, 1975. Internal Colonialism: The Celtic Fringe in British National Development. London: Routledge and Kegan Paul.

HERMAN, JOHN E. 2007. Amid the Clouds and Mist: China's Colonization of Guizhou, 12001700. Cambridge, Mass.: Harvard University Asia Center: Distributed by Harvard University Press.

HEVIA, JAMES, 1993. Cherishing Men From Afar: Qing Guest Ritual and the Macartney Embassy of 1793. London: Duke University Press.

HO, PING-Ti, 1998. "In Defense of Sinicization: A Rebuttal of Evelyn Rawski's "Reenvisioning the Qing." The Journal of Asian Studies 57(1):123-155.

HOBSON, J. A. 1948. Imperialism, a Study. London: G. Allen \& Unwin Ltd.

HOSTETLER, LAURA, 2000. “Qing Connections to the Early Modern World: Ethnography and Cartography in Eighteenth-Century China." Modern Asian Studies 34(3):623-62.

HSU CHO-YUN, 2012. China: A New Cultural History. New York: Columbia University Press. HSU CHO-YUN, 2015. Shuo Zhongguo: yi ge bu duan bianhua de fuza gongtongti (Talking of China: An Endlessly Changing Complex Community). Guilin: Guangxi Shifan Daxue Chubanshe.

IVISON, DUNCAN, 2002. Postcolonial Liberalism. Cambridge: Cambridge University Press. JACOBS, JUSTIN M., 2016. Xinjiang and the Modern Chinese State. Seattle: University of Washington Press.

JAMESON, FREDRIC, 2002. A Singular Modernity: Essay on the Ontology of the Present. London: Verso.

JASANOFF, SHEILA, 2004. “The Idiom of Co-Production.” In States of Knowledge: The CoProduction of Science and Social Order, edited by Sheila Jasanoff, 1-12. London: 
Routledge.

JENCO, LEIGH, 2019. "Can the Chinese Nation Be One? Gu Jiegang, Chinese Muslims, and the Reworking of Culturalism." Modern China 45(6):595-628.

KARL, REBECCA E. 2002. Staging the World: Chinese Nationalism at the Turn of the Twentieth Century. Durham: Duke University Press.

KIVELSON, VALERIE A., and RONALD SUNY, 2017. Russia's Empires. New York: Oxford University Press.

KRAMER, PAUL A. 2011. "Power and Connection: Imperial Histories of the United States in the World." American Historical Review 116(5):1348-1391.

KUMAR, KRISHNAN, 2010. “Nation-States as Empires, Empires as Nation-States: Two Principles, One Practice?" Theory and Society 39(2):119-143.

LANGLOIS, JOHN D. 1980. "Chinese Culturalism and The Yüan Analogy: SeventeenthCentury Perspectives," Harvard Journal of Asiatic Studies 40(2):355-98.

LEE BYUNG HO, 2011. Forging the Imperial Nation: Imperialism, Nationalism and Ethnic Boundaries in China's Longue Duree. PhD Thesis: University of Michigan.

LEIBOLD, JAMES, 2004. "Positioning 'minzu’ within Sun Yat-Sen's Discourse of Minzu zhuyi." Journal of Asian History 38(2):163-213.

LEIBOLD, JAMES, 2006. “Competing Narratives of Racial Unity in Republican China From the Yellow Emperor to Peking Man.” Modern China 32(2):181-220.

LENIN, VLADIMIR IL'ICH, 1970. Imperialism, the Highest Stage of Capitalism: a Popular Outline. Peking: Foreign Language Press.

LEVENSON, JOSEPH R., 1952. "T'ien-Hsia and Kuo, and the 'Transvaluation of Values." The Far Eastern Quarterly 11 (4): 447-51. 
LEVENSON, JOSEPH, 1958. Confucian China and its Modern Fate: A Trilogy. Berkeley:

University of California Press.

LI AIYONG, 2016. "New Qing History and the Problem of "Chinese Empire"-Another Impact and Response?" Contemporary Chinese Thought 47 (1): 13-29.

LI ZHITING, 2003. "Jiagou zhongguo bianjiang xue de kexue shijian (Constructing a Scientific Practice for China's Borderland Studies)." Zhongguo bianjiang shi di yanjiu (China's Borderland History and Geography Studies) 13(3):95-100.

LI ZHITING, 2015. “'Xin Qingshi’: ‘xin diguo zhuyi’ shixue biaoben” (“The 'New Qing History": An Example of Neo-imperialist History." Last Modified 20 April 2015. http://sscp.cssn.cn/xkpd/zm_20150/201504/t20150420_1592234.html.

LIANG QICHAO, 1994. "Zhongguo shi xulun (Outline of Chinese History)” in yinbingshi hejiwenji, vol. 6. Beijing: zhonghua shuju.

LIEVEN, DOMINIC, 2003. Empire: the Russian Empire and its Rivals from the Sixteenth Century to the Present. London: Pimilico.

LIU, ANDREW B. 2019. "Production, Circulation, and Accumulation: The Historiographies of Capitalism in China and South Asia." The Journal of Asian Studies 78 (4): 767-88.

MA DAZHENG and SHAN, PATRICK FULIANG, 2009. "Frontier History in China: A Scholarly Dialogue Across the Pacific Ocean.” The Chinese Historical Review 19(1):6578.

MILLWARD, JAMES, 1998. Beyond the Pass: Economy, Ethnicity, and Empire in Qing Central Asia, 1759-1864. Stanford, Calif: Stanford University Press.

MITCHELL, TIMOTHY, 2007. Colonising Egypt. Cambridge: Cambridge University Press. 
MORRISON, ALEXANDER, 2012. “How 'Modern' Was Russian Imperialism?” in Empire and After: Essays in Comparative Imperial and Decolonization Studies, edited by Tomohiko Uyama, 1-17. Saporo: Slavic Research Centre Hokkaido University.

MORRISON, ALEXANDER, 2012. "The Pleasures and Pitfalls of Colonial Comparisons." Kriticka: Explorations of Russian and Eurasion History 13(4):919-936.

MUELLER, JUSTIN, 2016. “Temporality, Sovereignty, and Imperialism: When is Imperialism?" Politics 36(4):428-440.

NEWBY, LAURA, 2005. The Empire and the Khanate: A Political History of Qing Relations with Khoqand c. 1760-1860. Leiden: Brill.

NOTELHELFER, F.G. 1971. Kōtoku Shūsui: Portrait of a Japanese Radical. Cambridge: Cambridge University Press.

OIDTMANN, MAX. 2018. Forging the Golden Urn: The Qing Empire and the Politics and the Politics of Reincarnation in Tibet. New York: Columbia University Press.

PAGDEN, ANTHONY, 1995. Lords of All the World: Ideologies of Empire in Spain, Britain and France : C.1500-c.1800. New Haven, Conn.; London: Yale University Press.

PERDUE, PETER, 1998a. "Boundaries, Maps, and Movement: Chinese, Russian, and Mongolian Empires in Early Modern Central Eurasia." The International History Review 20(2):263-86.

PERDUE, PETER, 1998b. “Comparing Empires: Manchu Colonialism.” International History Review 20(2):255-262.

POMERANZ, KENNETH, 2005. “Empire and 'Civilizing' Missions, Past \& Present.” Daedalus 134(2): $34-45$. 
PORTER, ANDREW, 1997. ““Cultural imperialism’ and protestant missionary enterprise, 17801914," The Journal of Imperial and Commonwealth History 25(3):367-391.

OIDTMANN, MAX, 2018. Forging the Goldern Urn: The Qing Empire and the Politics of Reincarnation in Tibet. New York: Columbia University Press.

OU LIDE (Mark Elliott), 2014. “Chuantong Zhongguo shi yi ge diguo ma? (Was Traditional China an Empire?)." Dushu 01:29-40.

RAWSKI, EVELYN SAKAKIDA, 1996. "Presidential Address: Reenvisioning the Qing: The Significance of the Qing Period in Chinese History.” The Journal of Asian Studies 55(4):829-50.

RICHARDSON, BENJAMIN J. 2009. "The Dyadic Character of US Indian Law” in Indigenous Peoples and the Law: Comparative and Critical Perspectives edited by Benjamin J. Richardson, 51-79. Oxford: Hart.

SAID, EDWARD W. 1994. Culture and Imperialism. London: Vintage.

SCHNEIDER, AXEL, 2001. "Bridging the Gap: Attempts at Constructing a 'New' HistoricalCultural Identity in the PRC." East Asian History 22:129-144.

SCHNEIDER, JULIA C. 2017. Nation and Ethnicity: Chinese Discourses on History, Historiography and Nationalism (1900s-1920s). Leiden: Brill.

SCOTT, JAMES C. 1998. Seeing like a State: How Certain Schemes to Improve the Human Condition Have Failed. New Haven: Yale University Press.

STARY, GIOVANNI. 2013. Giovanni Stary: Selected Manchu Studies. Edited by Hartmut Walravens. Studien Zur Sprache, Geschichte Und Kultur Der Turkvölker 17. Berlin: Klaus Schwarz, 2013.

STOLER, ANN LAURA, 2006. “On Degrees of Imperial Sovereignty.” Public Culture 
18(1):125-146.

SUN ZHE and WANG JIANG, 2013. Bianjiang, minzu, guojia: Yugong banyuekan yu ershi shiji sanshi sishi niandai de Zhongguo bianjiang yanjiu (Frontier, Nation and State: Yugong Semimonthly and Chinese Frontier Studies in 1930-40s). Beijing: Renmin daxue chubanshe.

TENG, EMMA, 2006. Taiwan's Imagined Geography: Chinese Colonial Travel Writing and Pictures, 1683-1895. Cambridge, Mass.: Harvard University Press.

TONG SHUYE, 1934. “'Man Xia' Kao’ (Investigating the Difference Between Han and NonHan)." Yugong 8:25-26.

WALEY-COHEN, JOANNA, 2004. “The New Qing History.” Radical History Review 88(1):193-206.

WANG JIANWEI, 2012. "The Chinese Interpretation of the Concept of Imperialism in the AntiImperialist Context of the 1920s." Journal of Modern Chinese History 6(2):164-181.

WANG RONGZU, 2016. “wei ‘xin Qing shi' bianhu xu xian dongde 'xin Qing shi': jing da Yao Dali xiansheng" in shufang wei yuan: gudai zhongguo de jiangyu, minzu yi rentong (Distant Regions are not Far: Ancient China's Territory, Peoples and Identity) edited by Wang Rongzu, Ge Zhaoguang, Yao Dali and Xu Wenkan, 324-339. Beijing: Zhonghua shuju.

WANG XIUYU, 2011. China's Last Imperial Frontier: Late Qing Expansion in Sichuan's Tibetan Borderlands. Lanham: Lexington.

WEBER, EUGENE, 1976. Peasants into Frenchmen: The Modernization of Rural France, 18701914. Stanford: Stanford University Press.

WEINSTEIN, JODI L. 2014. Empire and Identity in Guizhou: Local Resistance to Qing 
Expansion. Seattle: University of Washington Press.

XU HONG, 2016. "Xin Qing shi lunzheng zi xingqi: He, Luo lunzhan (The Origins of the New Qing History Controversy: The Debate Between Ho Ping-ti and Evelyn Rawski)". Shoudu shifan daxue xuebao, (shehuike xueban) (Journal of Capital Normal University, Social Science Division) 2016 (1).

YAO DALI, 2016a. "lüe wu qu jing, ke wei wo yong - jian da Wang Rongzu (Sort the Wheat from the Chaff for Us to Use - Responding to Wang Rongzu)" in shufang wei yuan: gudai zhongguo de jiangyu, minzu yi rentong (Distant Regions are not Far: Ancient China's Territory, Peoples and Identity) edited by Wang Rongzu, Ge Zhaoguang, Yao Dali and Xu Wenkan, 340-362. Beijing: Zhonghua shuju.

YAO DALI, 2016b. “"xin qing shi’ zhi zheng beihou de minzuzhuyi - keyi cong 'xin qing shi’ xuexi shenme (The 'Nationalism' Behind the 'New Qing History' Dispute - What can we Learn From 'New Qing History?')" in shufang wei yuan: gudai zhongguo de jiangyu, minzu yi rentong (Distant Regions are not Far: Ancient China's Territory, Peoples and Identity) edited by Wang Rongzu, Ge Zhaoguang, Yao Dali and Xu Wenkan, 300-323. Beijing: Zhonghua shuju.

YOUNG, IRIS MARION, 1990. Justice and the Politics of Difference. Princeton, N.J.: Princeton University Press.

ZHANG MINGYANG and DING XIONGFEI, 2016. "Ge Zhaoguang zai tan 'cong zhoubian kan zhongguo' (Ge Zhaoguang Again Discusses 'Viewing China from the Periphery')” in shufang wei yuan: gudai zhongguo de jiangyu, minzu yi rentong (Distant Regions are not Far: Ancient China's Territory, Peoples and Identity) edited by Wang Rongzu, Ge Zhaoguang, Yao Dali and Xu Wenkan, 13-29. Beijing: Zhonghua shuju. 
ZHAO TINGYANG, 2009. “A Political World Philosophy in Terms of All-Under-Heaven (tianxia)." Diogenes 56(5):5-18.

\footnotetext{
${ }^{1}$ Manchu, Mongol and Tibetan studies have long been established in continental European and Russian academic circles (e.g. Stary 2013); however, this scholarship has generally not been targeted by Chinese critics of the New Qing History. I am indebted to Joachim Kurtz for discussions on this point.

2 The definitive historical dictionary the Hanyu da cidian offers the first definition of diguo simply as "a state ruled by an emperor, with a monarchical system of government."

${ }^{3}$ Here we follow Sheila Jasanoff's influential definition of "co-production" as an "idiom" for interpreting complex social phenomena in ways that account for the interaction of knowledge and empirical experience (2004, 3). But we extend its meaning, to also include the conceptual innovations that emerge at the intersection of differently-situated cultural and political contexts.

4 The study of Manchu and Manchukuo also gained ground among certain German and Italian scholars in the 1930s, whose fascist governments supported Japanese imperial ambitions in China.
} 